\title{
Pengaruh Media Leaflet Terhadap Pengetahuan dan Sikap Dalam Upaya Pencegahan Covid-19 Pada Pedagang di Pasar Tradisional Oesapa Kota Kupang
}

\author{
The Effect of Leaflet Media on Knowledge and Attitude \\ In Efforts to Prevent Covid-19 on Traders at the Oesapa Traditional Market, Kupang City
}

\author{
Sintha Lisa Purimahua*1, Indriati Andolita Tedju Hinga ${ }^{1}$, Ribka Limbu ${ }^{1}$,Sarinah Basri K. ${ }^{2}$
}

${ }^{1}$ Program Studi Ilmu Kesehatan Masyarakat, FKM, Universitas Nusa Cendana, Kupang

${ }^{2}$ Program Studi Ilmu Kesehatan Masyarakat, FKM, Universitas Wiralodra, Indramayu e-mail: ${ }^{* 1}$ sinthalisa@gmail.com, ${ }^{2}$ indriati.teddjuhinga@ staf.undana.ac.id,

${ }^{3}$ Limburibka10@gmail.com, ${ }^{4}$ b.sarinah99@gmail.com

\begin{abstract}
Abstrak
Pengetahuan yang tepat dan memiliki sikap yang benar dapat mencegah penularan Covid-19. Melalui media leafleat dalam upaya pencegahan dapat berdampak positif karena membentuk keyakinan orang untuk beriperilaku sesuai keyakinannya. Penelitian ini bertujuan mengetahui pengaruh media leaflet terhadap pengetahuan dan sikap dalam upaya pencegahan Covid-19 pada pedagang di Pasar Oesapa Kota Kupang. Jenis penelitian ini adalah penelitian analitik dengan pendekatan Pra Eksperimen. Jumlah sampel pada penelitian ini berjumlah 30 responden. Berdasarkan analisis univariat, responden lebih banyak usia 46-55 tahun (53.3\%), Jenis kelamin perempuan lebih banyak (53.3\%), pendidikan responden paling banyak adalah SD (56.7 \%), jenis pedagang paling banyak adalah pedagang sayur $(30.0 \%)$. Rerata nilai pengetahuan responden sebelum mendapatkan penyuluhan adalah 44.66 dan sesudah pemberian penyuluhan melalui media leaflet adalah 94.22 yang artinya terjadi peningkatan rerata nilai sebelum dan sesudah pemberian leaflet. Hasil pengujian hipotesis menggunakan uji Wilcoxon,diperoleh nilai z-score sebesar 4.807 dengan nilai $p$ value sebesar 0.000 yang artinya $p<0.005$ yang berarti Ada Pengaruh Peggunaan media leaflet terhadap Pengetahuan pedagang tentang Covid-19. Untuk variabel sikap, rerata nilai sikap responden sebelum mendapatkan penyuluhan adalah 72.85 dan sesudah pemberian penyuluhan melalui media leaflet adalah 97.46 yang artinya terjadi peningkatan rerata nilai sebelum dan sesudah pemberian leaflet. Hasil pengujian hipotesis menggunakan uji Wilcoxon,diperoleh nilai z-score sebesar 4.793 dengan nilai $p$ value sebesar 0.000 yang artinya $p<0.005$ yang berarti Ada Pengaruh Peggunaan media leaflet terhadap Sikap pedagang tentang Covid-19. Oleh karena itu direkomendasikan Puskesmas Oesapa agar lebih meningkatkan frekuensi kunjungan pemberian edukasi kesehatan kepada pedagang pasar tradisional di Kelurahan Oesapa.
\end{abstract}

Kata kunci: media leaflet, pedagang, pengetahuan, sikap

\begin{abstract}
The right knowledge and having the right attitude can prevent the transmission of COVID-19. Through leaflet media in prevention efforts can have a positive impact because it forms people's beliefs to behave according to their beliefs. This study aims to determine the effect of leaflet media on knowledge and attitudes in an effort to prevent Covid-19 among traders at the Oesapa Market, Kupang City. This type of research is analytic research with a pre-experimental approach. The number of samples in this study amounted to 30 respondents. Based on univariate analysis, the majority of respondents were aged 46-55 years (53.3\%), more female gender (53.3\%), The most education respondents are elementary school (56.7\%), the most type of traders are vegetable traders (30.0\%). The average value of respondents' knowledge before getting counseling was 44.66 and after giving counseling through leaflet media was 94.22 which means there was an increase in the average value before and after giving leaflets. The results of hypothesis testing using the Wilcoxon test, obtained a $z$-score of 4,807 with a $p$ value of 0.000 , which means $p<0.005$, which means there is an effect of using leaflet media on traders' knowledge about Covid-19. For the attitude variable, the average attitude value of respondents before receiving counseling was 72.85 and after giving counseling through leaflet media was 97.46 which means that there was an increase in the average value before and after giving leaflets. The results of hypothesis testing using the Wilcoxon test, obtained a zscore of 4.793 with a $p$ value of 0.000 which means $p<0.005$ which means there is an effect of using leaflet media on traders' attitudes about Covid-19. Therefore, it is recommended that the Oesapa Health Center increase the frequency of providing health education to traditional market traders in Oesapa Village
\end{abstract}

Keywords: media leaflets, traders, knowledge, attitudes. 


\section{Pendahuluan}

Pada awal tahun 2020, dunia dihebohkan dengan merebaknya virus baru yaitu virus corona yang bernama Coronavirus Disease 2019 (Covid-19). Virus ini diketahui terjadi di Wuhan, China yang pertama kali ditemukan pada akhir Desember $2019^{1}$. CDC dan US Department of Homeland Security's US Customs and Border Protection memulai pemeriksaan kesehatan di bandara AS untuk mengidentifikasi wisatawan sakit yang kembali dari kota Wuhan pada tanggal 17 januari 2020. Pada tanggal 31 Januari 2020, sebanyak 210 orang yang bergejala diuji, dari orang-orang ini sebelas diantaranya memiliki infeksi $2019-\mathrm{nCoV}^{2}$.

Dunia telah menyaksikan kematian dan kesakitan parah yang belum pernah terjadi sebelumnya karena penyakit ini yang mengakibatkan keadaan darurat kesehatan masyarakat yang serius. ${ }^{3}$. WHO menetapkan Covid-19 sebagai Public Health Emergency of International Concern (PHEIC) pada 30 Januari 2020 karena proses penularan yang cepat dan pada tanggal 11 Maret 2020 ditetapkan sebagai pandemi ${ }^{4}$. Pandemi Covid-19 berdampak tinggi pada kesehatan masyarakat di banyak negara ${ }^{5}$, setiap hari ada kasus baru dan kematian dilaporkan di seluruh dunia ${ }^{6}$.

Virus yang sangat menular ini dapat menyebabkan gejala klinis utama seperti demam, batuk kering, kelelahan, mialgia, dan dispnea ${ }^{7}$, dengan masa inkubasi 2-14 hari setelah terpapar virus. Virus ini dapat menyebabkan morbiditas di kisaran penyakit pernapasan ringan komplikasi parah yang ditandai dengan sindrom akut pernapasan distress, syok septik, dan gangguan metabolisme dan hemostasis lainnya, dan akhirnya kematian. Sebagian besar bentuk fatal Covid-19 termasuk sindrom pernapasan akut terjadi pada orang dewasa yang lebih tua dan orang-orang dengan komorbiditas medis yang mendasarinya ${ }^{8}$.

Pengobatan Covid-19 masih belum jelas dan tidak ada pengobatan antivirus yang terbukti efektif ${ }^{9}$, maka fokus pada peningkatan kesadaran masyarakat terkait dengan metode pencegahan sangat penting ${ }^{7}$. Untuk mengendalikan dan mencegah tertular dan menyebarkan Covid-19, orang perlu memiliki pengetahuan yang tepat tentang penyakit ini, memiliki sikap yang benar melawan virus ${ }^{10}$.

Pemahaman seseorang dapat dirubah melalui pengetahuan, dimana sebelumnya seseorang memahami bahwa Covid-19 hanya dapat ditularkan pada orang yang memiliki gejala saja, dengan memperoleh edukasi melalui media leafleat sehingga berdampak positif yang membentuk keyakinan orang untuk beriperilaku sesuai keyakinannya ${ }^{11}$. WHO melaporkan bahwa cara terbaik untuk mencegah dan memperlambat penularan Covid-19 adalah dengan menginformasikan secara akurat dan luas kepada masyarakat tentang penyakit, penyebab, cara penularan, dan cara pencegahan sederhana seperti cuci tangan pakai sabun atau penggunaan tangan. pembersih, menjaga jarak sosial dan tinggal di rumah agar tetap terlindungi dari infeksi ${ }^{12}$. Oleh karena itu tujuan penelitian ini adalah untuk mengetahui pengaruh media leaflet terhadap pengetahuan dan sikap dalam upaya pencegahan Covid-19 pada pedagang di Pasar Oesapa Kota Kupang.

\section{Metode Penelitian}

Jenis penelitian yang digunakan dalam penelitian ini adalah Pra Eksperiment yang digunakan untuk mengungkap hubungan sebab-akibat hanya dengan cara melibatkan satu kelompok subjek, sehingga tidak ada kontrol yang ketat terhadap variabel. Jenis rancangan penelitian adalah PretestPostest Kelompok Tunggal (The One Group Pretest Posttest). Model ini menggunakan tes awal (pretest) kemudian setelah diberikan perlakukan dilakukan pengukuran (posttest) lagi untuk mengetahui akibat dari perlakukan itu. 


\section{$\mathrm{O} 1 \times 02$}

$\mathrm{O} 1=$ nilai pretest (sebelum diberi leaflet)

$\mathrm{O} 2$ = nilai posttest (sesudah diberi leaflet)

Hasil perlakuan dapat diketahui lebih akurat, karena dapat membandingkan dengan keadaan (pengetahuan dan sikap) sebelum dan sesudah diberi perlakuan.

Teknik sampling yang digunakan adalah Non random sampling. Non Random Sampling (purposive sampling) berarti pemilihan sekelompok subjek yang diperoleh melalui kriteria inklusi dan eksklusi. Dalam penelitian ini jumlah sampel sebanyak 30 orang pedagang di pasar tradisional Oesapa. Bagan alir penelitian pada gambar 1 dan tahapan penelitian pada gambar 2 .

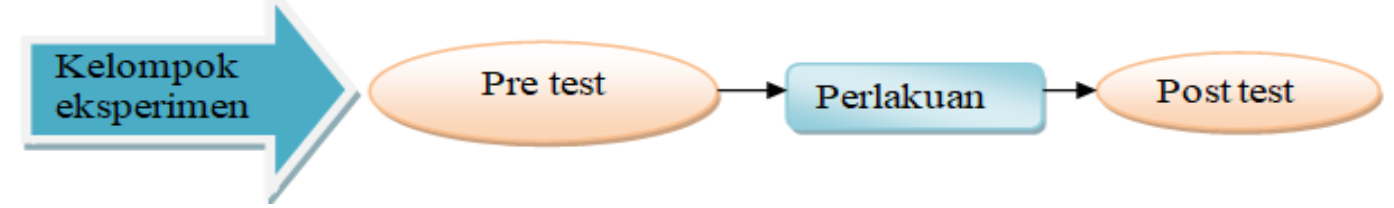

Gambar 1. Bagan Alir Penelitian

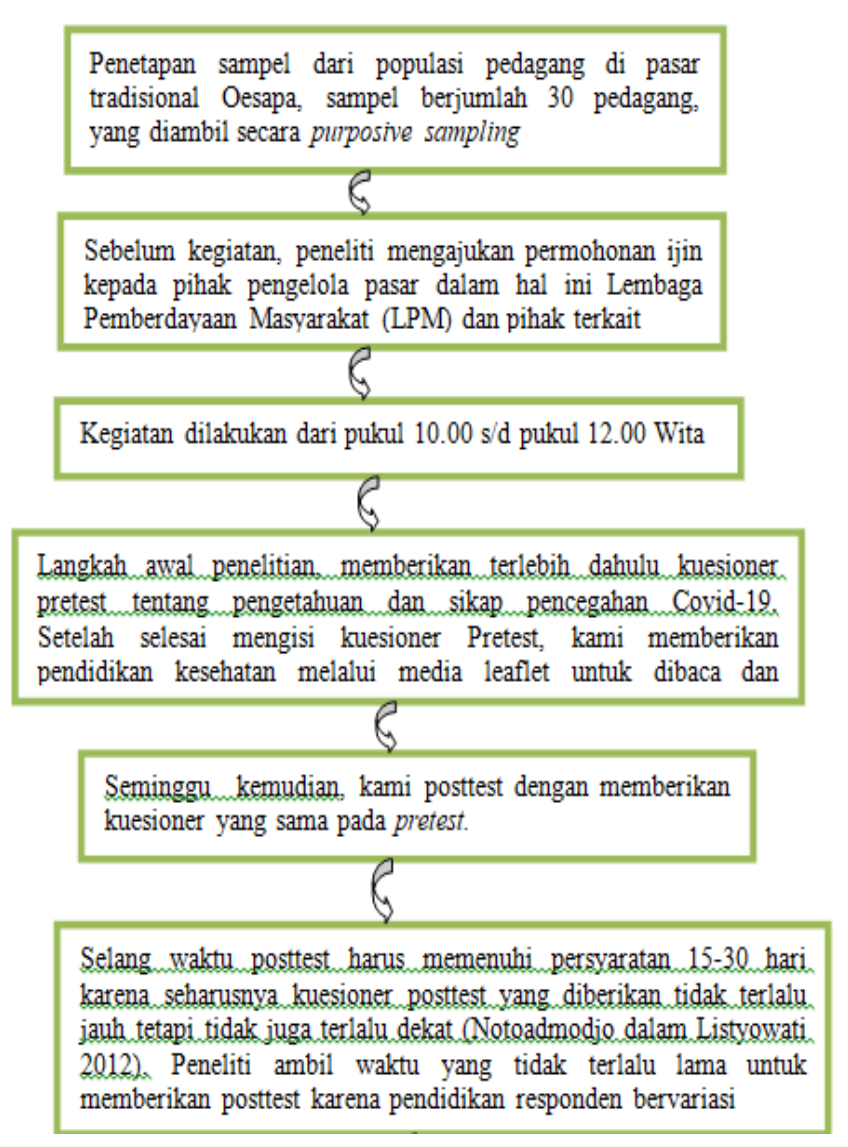

Gambar 2. Tahapan Penelitian 


\section{Hasil Penelitian}

\section{Analisis Univariat}

Analisis univariat dilakukan terhadap variabel-variabel dalam temuan yang digunakan untuk menggambarkan mengenai karakteristik masing-masing variabel penelitian ${ }^{13}$.

\subsection{Distribusi Frekuensi Usia Responden}

Distribusi frekuensi berdasarkan usia responden yang mendapat pendidikan kesehatan melalui media leaflet dapat dilihat pada tabel 1 berikut:

Tabel 1. Distribusi Frekuensi Berdasarkan Usia Responden yang Mengikuti Penyuluhan Upaya Pencegahan Covid-19 dengan Media Leaflet Pada Pedagang di Pasar Tradisional Oesapa Kota Kupang Tahun 2021.

\begin{tabular}{clcc}
\hline No & Usia & N & Presentase (\%) \\
\hline 1 & Remaja Awal (12-16) Tahun & 1 & 3.3 \\
2 & Remaja Akhir (17-25) Tahun & 8 & 26.7 \\
3 & Dewasa Awal (36-45) Tahun & 2 & 6.7 \\
4 & Dewasa Akhir (46-55) Tahun & 2 & 6.7 \\
5 & Lansia Awal (46-55) Tahun & 16 & 53.3 \\
6 & Lansia Akhir (56-65) & 1 & 3.3 \\
\hline & Total & $\mathbf{3 0}$ & $\mathbf{1 0 0}$ \\
\hline
\end{tabular}

Tabel 1 menunjukkan bahwa responden terbanyak dalam penelitian ini berada dalam kategori umur lansia awal (46-55) tahun sebanyak 16 orang (53.3\%) dan paling sedikit berada dalam kategori umur remaja awal (12-16) tahun dan lansia akhir (56-65) tahun sebanyak 1 orang $(3.3 \%)$.

\subsection{Distribusi Frekuensi Jenis Kelamin Responden}

Distribusi frekuensi berdasarkan jenis kelamin responden yang mendapat pendidikan kesehatan melalui media leaflet dapat dilihat pada tabel 2 berikut:

Tabel 2. Distribusi Frekuensi Responden Berdasarkan Jenis Kelamin yang Mengikuti Penyuluhan Upaya Pencegahan Covid-19 dengan Media Leaflet Pada Pedagang di Pasar Tradisional Oesapa Kota Kupang Tahun 2021

\begin{tabular}{lllc}
\hline No & Jenis Kelamin & N & Presentase (\%) \\
\hline 1 & Laki-laki & 14 & 46.7 \\
2 & Perempuan & 16 & 53.3 \\
\hline & Total & $\mathbf{3 0}$ & $\mathbf{1 0 0}$ \\
\hline
\end{tabular}

Tabel 2 menunjukkan bahwa responden terbanyak berjenis kelamin perampuan sebanyak 16 orang $(53.3 \%)$ dan responden paling sedikit berjenis kelamin laki-laki sebanyak 14 orang $(46.7 \%)$.

\subsection{Distribusi Frekuensi Berdasarkan Jenis Pedagang}

Distribusi frekuensi berdasarkan jenis dagangan responden yang mendapatkan pendidikan kesehatan dengan menggunakan media leaflet dapat dilihat pada tabel 3 berikut: 
Tabel 3. Distribusi Frekuensi Responden Berdasarkan Jenis Pedagang yang Mengikuti Penyuluhan Upaya Pencegahan Covid-19 dengan Media Leaflet di Pasar Tradisional Oesapa Kota Kupang Tahun 2021

\begin{tabular}{clcc}
\hline No & Jenis Pedagang & N & Presentase (\%) \\
\hline 1 & Pedagang Nasi & 4 & 13.3 \\
2 & Pedagang Ikan & 8 & 26.7 \\
3 & Pedagang Sayur & 9 & 30.0 \\
4 & Pedagang Sembako & 6 & 20.0 \\
5 & Pedagang Bumbu & 1 & 3.3 \\
6 & Pedagang Kue & 2 & 6.7 \\
\hline & Total & $\mathbf{3 0}$ & $\mathbf{1 0 0}$ \\
\hline
\end{tabular}

Berdasarkan Tabel 3 menunjukkan bahwa responden terbanyak terdapat pada pedagang sayur 9 orang (30.0\%) dan responden paling sedikit adalah pedagang bumbu 1 orang $(3.3 \%)$.

\subsection{Distribusi Frekuensi Berdasarkan Pendidikan}

Distribusi frekuensi berdasarkan pendidikan responden yang mendapat pendidikan kesehatan dengan menggunakan media leaflet dapat dilihat pada tabel 4 berikut:

Tabel 4. Distribusi Frekuensi Responden Berdasarkan Pendidikan Responden yang Mengikuti Penyuluhan Upaya Pencegahan Covid-19 dengan Media Leaflet Pada Pedagang di Pasar Tradisional Oesapa Kota Kupang Tahun 2021

\begin{tabular}{clcc}
\hline No & \multicolumn{1}{c}{ Pendidikan } & N & Presentase (\%) \\
\hline 1 & Kurang (SD) & 17 & 56.7 \\
2 & Cukup (SMP) & 3 & 10.0 \\
3 & Baik (SMA) & 6 & 20.0 \\
4 & Sangat Baik (Sarjana) & 4 & 13.3 \\
\hline & Total & $\mathbf{3 0}$ & $\mathbf{1 0 0 . 0}$ \\
\hline
\end{tabular}

Tabel 4 menunjukan bahwa jumlah responden terbanyak berpendidikan terakhir SD sebanyak 17 orang $(56.7 \%)$, responden dengan pendidikan terakhir SMA 6 orang (20.0\%), responden dengan pendidikan terakhir sarjana 4 orang $(13.3 \%)$ dan responden paling sedikit berpendidikan terakhir SMP sebanyak 3 orang $(10.0 \%)$.

\subsection{Distribusi Frekuensi Berdasarkan Pengetahuan Pedagang}

Distribusi frekuensi berdasarkan pengetahuan responden sebelum dan sesudah pemberian pendidikan kesehatan melalui media leaflet dapat dilihat pada tabel 5 berikut:

Tabel 5. Distribusi Frekuensi Responden Berdasarkan Pengetahuan Sebelum dan Sesudah Pemberian Leaflet Pencegahan Covid-19 Pada Pedagang di Pasar Tradisional Oesapa Kota Kupang

\begin{tabular}{lcccc}
\hline \multirow{2}{*}{ Pengetahuan } & \multicolumn{2}{c}{ Pre Test } & \multicolumn{2}{c}{ Post Test } \\
\cline { 2 - 5 } & $\mathbf{N}$ & $\begin{array}{c}\text { Presentase } \\
(\boldsymbol{\%})\end{array}$ & $\mathbf{N}$ & Presentase (\%) \\
\hline Baik & 0 & 0 & 27 & 90.0 \\
Cukup & 8 & 26.7 & 3 & 10.0 \\
Kurang & 22 & 73.3 & 0 & 0 \\
\hline \multicolumn{1}{c}{ Total } & $\mathbf{3 0}$ & $\mathbf{1 0 0 . 0}$ & $\mathbf{3 0}$ & $\mathbf{1 0 0 . 0}$ \\
\hline
\end{tabular}


Tabel 5 menunjukkan bahwa pengetahuan responden sebelum diberikan media leaflet sebagian besar responden berpengetahuan Kurang sebanyak 22 orang $(73.3 \%)$ dan setelah pemberian media leaflet sebagian besar responden berpengetahuan Baik sebanyak 27 orang $(90.0 \%)$.

\subsection{Distribusi Frekuensi Berdasarkan Sikap Pedagang}

Distribusi frekuensi berdasarkan sikap responden sebelum dan sesudah pemberian pendidikan kesehatan melalui media leaflet dapat dilihat pada tabel 6 berikut:

Tabel 6. Distribusi Frekuensi Responden Berdasarkan Sikap Sebelum dan Sesudah Pemberian Leaflet Pencegahan Covid-19 dengan Media Leaflet Pada Pedagang di Pasar Tradisional Oesapa Kota Kupang

\begin{tabular}{crcrc}
\hline Sikap & \multicolumn{2}{c}{ Pre Test } & \multicolumn{2}{c}{ Post Test } \\
\cline { 2 - 5 } & N & Presentase (\%) & P & Presentase (\%) \\
\hline Baik & 0 & 0 & 28 & 93.3 \\
Cukup & 8 & 26.7 & 2 & 6.7 \\
Kurang & 22 & 73.3 & 0 & 0 \\
\hline Total & $\mathbf{3 0}$ & $\mathbf{1 0 0}$ & $\mathbf{3 0}$ & $\mathbf{1 0 0}$ \\
\hline
\end{tabular}

Tabel 6 menunjukan bahwa sikap responden sebelum diberikan media leaflet sebagian besar responden bersikap kurang sebanyak 22 orang $(73.3 \%)$ dan setelah pemberian media leaflet sebagian besar responden berpengetahuan baik sebanyak 28 orang (93.3\%).

\section{Analisis Bivariat}

Analisis bivariat yaitu untuk menganalisis variabel-variabel penelitian yang bertujuan menguji hipotesis penelitian serta untuk melihat gambaran hubungan antara variabel penelitian ${ }^{13}$.

\subsection{Uji Normalitas}

Hasil uji normalitas pedagang yang mendapat leaflet tentang pencegahan Covid-19 dengan menggunakan uji Kolmogorov-smirnov dapat dilihat pada tabel 7 berikut:

Tabel 7. Hasil Uji Normalitas Responden yang Mendapat Media Leaflet Pencegahan Covid-19 Pada Pedagang di Pasar Tradisional Oesapa Kota Kupang Tahun 2021

\begin{tabular}{lccc}
\hline \multirow{2}{*}{ Keterangan } & \multirow{2}{*}{ df } & \multicolumn{2}{c}{ Kolmonogorov-smirnov } \\
\cline { 3 - 4 } & & Statistic & Sig \\
\hline Pretest Pengetahuan & 30 & 0.245 & 0.000 \\
Posttest Pengetahuan & 30 & 0.289 & 0.000 \\
Pretest Sikap & 30 & 0.223 & 0.001 \\
Posttest Sikap & 30 & 0.268 & 0.000 \\
\hline
\end{tabular}

Tabel 7 menunjukkan hasil uji normalitas menggunakan kolmonogorov-smirnov data tidak berdistribusi normal $(\mathrm{p}<0.05)$, oleh karena itu penelitian ini harus menggunakan uji wilcoxon.

\subsection{Pengaruh Media Leaflet Terhadap Pengetahuan Sebelum dan Sesudah Penyuluhan Pencegahan Covid-19 pada Pedagang}

Analisis pengaruh media leaflet terhadap pengetahuan sebelum dan sesudah penyuluhan pencegahan Covid-19 pada pedagang dapat dilihat pada Tabel 8 berikut: 
Tabel 8. Pengaruh Media Leaflet Terhadap Pengetahuan Sebelum dan Sesudah Penyuluhan Pencegahan Covid-19 dengan Media Leaflet pada Pedagang di Pasar Tradisional Oesapa Kota Kupang Tahun 2021

\begin{tabular}{cccccc}
\hline Pengetahuan & N & Mean & SD & $\begin{array}{c}\text { P-value } \\
\text { (2-tailed) }\end{array}$ & Z Score \\
\hline Pretest & 30 & 44.66 & $\begin{array}{r}12.521 \\
6.246\end{array}$ & 0.000 & 4.807 \\
Posttest & 30 & 94.22 & & \\
\hline
\end{tabular}

Berdasarkan Tabel 8 diketahui bahwa rerata nilai pengetahuan responden sebelum mendapatkan penyuluhan adalah 44.66 sedangkan rerata nilai setelah mendapat penyuluhan adalah 94.22 artinya terjadi peningkatan rerata nilai sebelumdan sesudah pemberian media leaflet. Hasil pengujian hipotesis menggunakan uji wilcoxon diperoleh nilai zscore sebesar 4.807 dengan $\mathrm{p}$ value sebesar $0.000(\mathrm{p}<0.05)$, hal ini berarti ada pengaruh penggunaan media leaflet terhadap pengetahuan pedagang tentang Covid-19.

\subsection{Pengaruh Media Leaflet Terhadap Sikap Sebelum dan Sesudah Penyuluhan Pencegahan Covid-19 pada Pedagang di Pasar Tradisional Oesapa Kota Kupang}

Analisis pengaruh media leaflet terhadap sikap sebelum dan sesudah penyuluhan pencegahan Covid-19 pada pedagang dapat dilihat pada tabel 9 berikut:

Tabel 9. Pengaruh Media Leaflet Terhadap Sikap Sebelum dan Sesudah Penyuluhan Pencegahan Covid-19 pada Pedagang di Pasar Tradisional Oesapa Kota Kupang Tahun 2021

\begin{tabular}{cccccc}
\hline Sikap & N & Mean & SD & $\begin{array}{c}\text { P-value } \\
\text { (2-tailed) }\end{array}$ & Z Score \\
\hline Pretest & 30 & 72.85 & 6.300 & 0.000 & 4.793 \\
Posttest & 30 & 97.46 & 2.993 & & \\
\hline
\end{tabular}

Berdasarkan Tabel 9 diketahui bahwa rerata nilai sikap responden sebelum mendapat penyuluhan adalah 72.85 sedangkan rerata nilai setelah mendapat penyuluhan adalah 97.46 , artinya terjadi peningkatan rerata nilai sebelum dan sesudah penyuluhan. Hasil pengujian hipotesis menggunakan uji wilcoxon diperoleh nilai zscore sebesar 4.793 dengan $p$ value sebesar $0.000(\mathrm{p}<0.05)$ hal ini berarti ada pengaruh penggunaan media leaflet terhadap sikap pedagang tentang Covid-19.

\section{Pembahasan}

1. Pengaruh Media Leaflet Terhadap Perubahan Pengetahuan Sebelum dan Sesudah Pemberian Media leaflet pada Pedagang di Pasar Tradisional Oesapa Kota Kupang

Pengetahuan adalah hasil tahu, ini terjadi setelah seseorang melakukan pengindraan terhadap suatu objek. Pengindraan terjadi melalui pancaindra manusia yaitu: indra pengelihatan, pendengaran, penciuman, rasa dan raba. Sebagian besar pengetahuan manusia didapatkan melalui mata dan telinga ${ }^{14}$. Media leaflet atau yang biasa disebut pamplet merupakan media pembelajaran yang praktis dan efektif karena mudah dipahami oleh pembaca serta dapat dibawa kemana-mana karena bentuknya yang praktis dan sederhana hanya berupa lembaran berisikan informasi atau tulisan dan gambaran yang menarik minat pembaca ${ }^{15}$.

Hasil penelitian menunjukan bahwa pendidikan kesehatan dengan menggunakan media leaflet dapat meningkatkan pengetahuan responden dengan kategori baik. Pengetahuan responden 
sebelum diberi media leaflet sebagian besar berpengetahuan kurang 22 orang $(73.3 \%)$ dan setelah diberi media leaflet sebagian besar berpengetahuan baik sebanyak 27 orang $(90.0 \%)$. Hasil penelitian ini didukung oleh penelitian yang dilakukan oleh Purnamasari yang berjudul "upaya peningkatan pengetahuan pencegahan Covid-19 dengan menggunakan media leaflet pada pasien rawat jalan di UPTD Puskesmas Pare Kabupaten Kediri 2021" yang menunjukan bahwa pengetahuan responden sebelum diberikan media leaflet sebagian besar responden berpengetahuan cukup (45\%) setelah diberikan media leaflet responden perpengetahuan baik $(40 \%)$, berpengetahuan cukup (35\%), dan berpengetahuan kurang $(25 \%)$. Hal ini menunjukakan terjadi peningkatan pengetahuan responden sebelum dan sesudah diberikan media leaflet 16. Pengetahuan yang baik tentang pencegahan penyebaran penyakit Covid-19 pada masa pandemi ini akan memberikan pengaruh pada sikap dan selanjutnya pada perilaku seseorang. Pemahaman yang baik mengenai pencegahan penyakit ini akan mendorong terbentuknya sikap positif dan selanjutnya terwujudnya tindakan yang baik dan benar pula.

Hasil uji wilcoxon yang telah dilakukan menunjukkan ada pengaruh yang signifikan antara pendidikan kesehatan menggunakan media leaflet terhadap pengetahuan pencegahan Covid-19 pedagang dengan $p$-value $0.000(\mathrm{p}<0.05)$. Hasil penelitian ini sejalan dengan penelitian Martini dkk yang menyatakan ada perbedaan yang bermakna dari pengetahuan pedagang di pasar Benyuning sebelum dan sesudah dilakukan pendidikan kesehatan dengan menggunakan media leaflet dengan $p$ value 0.000 ( $\mathrm{p}<0.05) .{ }^{17}$ Penelitian ini juga sejalan dengan penelitian Wulandari yang menyatakan terdapat perbedaan yang signifikan antara pengetahuan pedagang di car free day Temanggung sebelum dan sesudah dilakukan pendidikan kesehatan menggunkan media leaflet dengan $p$-value 0.048 ( $\mathrm{p}<0.05) .{ }^{18}$ Penelitian ini juga sejalan dengan penelitian Jaji yang menyatakan terdapat perbedaan yang signifikan antara oengetahuan warga sebelum dilakukan pendidikan kesehatan menggunakan leaflet dengan pengetahuan warga setelah dilakukan pendidikan kesehatan menggunakan leaflet dengan pengetahuan warga setelah dilakukan pendidikan kesehatan menggunakan leaflet dengan $p$-value $0.001(\mathrm{p}<0.05){ }^{19}$. Demikian pula dengan penelitian yang dilakukan oleh Tedju Hinga, mengenai efektifitas penggunaan media poster dan leaflet dalam pendidikan kesehatan reproduksi efektif meningkatkan pengetahuan pada anak, remaja dan orang tua dengan nilai signifikansi $(\rho) 0,00<(\alpha) 0,05$ dan $(\rho) 0,02<(\alpha) 0$, $05 . .^{20}$

2. Pengaruh Pendidikan Kesehatan Menggunakan Media Leaflet Terhadap Perubahan Sikap Sebelum dan Sesudah Pemberian Media leaflet pada Pedagang di Pasar Tradisional Oesapa Kota Kupang

Sikap merupakan suatu reaksi atau respon yang masih tertutup dari seseorang terhadap stimulusatau objek tertentu. Sikap secara nyata menunjukan konotasi adanya kesesuaian reaksi terhadap stimulus tertentu yang dalam kehidupan sehari-hari merupakan reaksi yang bersifat emosional terhadap stimulus sosial. Sikap belum merupakan suatu tindakan atau aktivitas tetapi merupakan predisposisi tindakan suatu perilaku ${ }^{15}$.

Hasil penelitian ini menunjukan bahwa pendidikan kesehatan dengan menggunakan media leaflet dapat meningkatkan sikap responden sebelum dan sesudah pemberian media leaflet. Sikap responden sebelum diberikan media leaflet sebagian besar bersikap kurang sebanyak 22 orang $(73.3 \%)$ dan setelah diberikan media leaflet sebagian besar bersifat baik 28 orang (93.3\%). Hasil penelitian ini didukung oleh penelitian Wulan dkk yang berjudul "penyuluhan protokol kesehatan dengan media video dan leaflet terhadap penetahuan dan sikap lansia tentang pencegahan Covid-19 di Desa Sidodadi Ramunia Kecamatan Beringin Kabupaten Deli Serdang” 
menunjukkan bahwa sikap lansia terhadap pencegahan Covid-19 saat sebelum pemberian media video dan leaflet mayoritas bersifat negatif 15 orang $(75 \%)$ dan 5 orang bersifat positif $(25 \%)$ dan setelah pemberian media video dan leaflet mayoritas responden bersifat positif 14 orang $(70 \%)$ dan 6 orang (30\%), hal ini menunjukan terjadi peningkatan sikap responden sebelumdan sesudah diberikan media video dan leaflet. ${ }^{21}$

Hasil penelitian ini juga sejalan dengan penelitian Maryani yang berjudul "pengaruh leaflet Covid-19 terhadap ibu dan bayi pada masa pandemi di praktik mandiri bidan di Kota Bengkulu" menunjukkan bahwa adanya perubahan sikap sebelum dan sesudah pemberian leaflet yaitu sebelum pemberian leaflet yang bersikap positif sebesar 14 orang $(22.86 \%)$ dan setelah pemberian leaflet menjadi 22 orang $(62.86 \%)$ sedangkan yang bersikap negatif sebelum pemberian leaflet sebanyak 21 orang $(60 \%)$ menjadi 13 orang $(37,14 \%)$ setelah pemberian media leaflet, dapat disimpulkan bahwa terjadi peningkatan sikap bidan setelah diberikan media leaflet dalam pencegahan infeksi dan protokol pelayanan pasien maternal dan neonatal saat pandemi Covid-19. ${ }^{22}$

Hasil penelitian ini juga sejalan dengan penelitian Darmayanti yang menunjukan adanya perubahan sikap terhadap pemilihan jajanan sehat sebelum dan sesudah pemberian media leaflet yaitu sebelum pemberian media leaflet sebanyak 28 siswa $(77.8 \%)$ bersikap positif terhadap jajanan sehat dan 8 orang $(22.22 \%)$ bersikap negatif. Setelah pemberian media leaflet terjadi peningkatan sikap positif menjadi 34 siswa (91.7\%) sedangkan sikap negatif turun manjadi 2 siswa $(8.3 \%)$ oleh karena itu dapat disimpulkan terjadi peningkatan sikap siswi setelah pemberian media leaflet mengenai pemilihan jajanan sehat. ${ }^{23}$ Sikap seseorang terhadap pencegahan penyebaran Covid-19 akan mempengaruhi tindakan pencegahan yang dilakukan, dimana sikap yang positif dan mendukung terbentuknya perilaku pencegahan yang positif pula. Demikian pula dengan hasil penelitian Tedju Hinga mengenai edukasi kesehatan reproduksi pada murid sekolah Pendidikan Anak Usia Dini (PAUD), yang menunjukkan hasil bahwa pengetahuan dan keterampilan anak-anak setelah konseling berbasis media meningkat sebesar $92 \%$, sedangkan dalam konseling non-media hanya $63 \%$. Oleh sebab itu alat bantu media penyuluhan sangat mempengaruhi tingkat keberhasilan suatu penyuluhan atau pendidikan kesehatan, sebab hasil uji wilcoxon pada penelitian yang telah dilakukan ini, menunjukkan adanya pengaruh yang signifikan antara pendidikan kesehatan dengan menggunakan media leaflet terhadap sikap pencegahan Covid-19 pada pedagang dengan $p$-value $0.000(\mathrm{p}<0.05) .{ }^{20}$

\section{Kesimpulan}

1. Analisis Univariat, usia responden paling banyak lansia awal (46-55 tahun) sebanyak (53.3\%), Jenis kelamin perempuan lebih banyak $(53.3 \%)$, jenis dagangan responden paling banyak pedagang sayur (30\%), pendidikan SD yang paling banyak $(56.7 \%)$

2. Pengetahuan responden sebelum dan sesudah pemberian leaflet adalah sebagian besar berpengetahuan Kurang $(73.3 \%)$ dan setelah pemberian leaflet sebagian besar berpengetahuan Baik $(90 \%)$

3. Sikap responden sebelum dan sesudah pemberian leaflet adalah sebagian besar bersikap Kurang $(73.3 \%)$ dan setelah pemberian leaflet sebagian besar bersikap Baik $(93.3 \%)$

4. Hasil uji statistik menggunakan uji Wilcoxon, diperoleh nilai z-score sebesar 4.807 dengan pvalue 0.000 yang artinya $\mathrm{p}<0.005$ yang berarti Ada Pengaruh pemberian leaflet terhadap Pengetahuan pedagang pasar tradisional 
5. Hasil uji statistik menggunakan uji Wilcoxon, diperoleh nilai $z$-score sebesar 4.793 dengan pvalue 0.000 yang artinya $p<0.005$ yang berarti Ada Pengaruh pemberian leaflet terhadap Sikap pedagang pasar tradisional

\section{Saran}

1. Khususnya puskesmas Oesapa agar meningkatkan frekuensi kunjungan pemberian edukasi kesehatan kepada pedagang pasar tradisional di Kelurahan Oesapa Kota Kupang.

2. Perlu peningkatan upaya promosi kesehatan pada sector informal untuk meningkatkan pengetahuan dan sikap masyarakat khususnya pedagang pasar tradisional tentang dampak dari pandemic Covid-19.

3. Sosialisasi juga dilakukan kepada pengelola pasar untuk lebih aktif dalam mencegah penularan Covid-19 seperti di berbagai lokasi atau titik masuk pasar dengan menyediakan tempat cuci tangan, air dan sabun, memantau penggunaan masker pada pembeli dan pedagang, pengecekan suhu, secara berkala melakukan penyemprotan diinsefektan serta agar menghindarari adanya kerumunan dengan penataan kembali lingkungan pasar yang kondusif.

\section{Daftar Pustaka}

1. Yuliana Y. Corona virus diseases (Covid-19): Sebuah tinjauan literatur. Wellness Heal Mag. 2020;2(1):187-192. doi:10.30604/well.95212020

2. Bajema KL, Oster AM, McGovern OL, et al. Persons Evaluated for 2019 Novel Coronavirus United States, January 2020. MMWR Morb Mortal Wkly Rep. 2020;69(6):166-170.

3. Hager E, Odetokun IA, Bolarinwa O, Zainab A, Okechukwu O, Al-Mustapha AI. Knowledge, attitude, and perceptions towards the 2019 Coronavirus Pandemic: A bi-national survey in Africa. PLoS One. 2020;15(7 July):1-13. doi:10.1371/journal.pone.0236918

4. Keputusan Menteri Kesehatan Republik Indonesia. Keputusan Menteri Kesehatan Republik Indonesia Nomor HK.01.07/MenKes/413/2020 Tentang Pedoman Pencegahan dan Pengendalian Corona Virus Disease 2019 (Covid-19). MenKes/413/2020. 2020;2019:207.

5. Group BC-A. Early indicators of intensive care unit bed requirement during the COVID-19 epidemic: A retrospective study in Ile-de-France region, France. PLoS One. 2020;15(11 November):1-12. doi:10.1371/journal.pone.0241406

6. Qutob N, Awartani F. Knowledge, attitudes and practices (KAP) towards COVID-19 among Palestinians during the COVID-19 outbreak: A cross-sectional survey. PLoS One. 2021;16(1 January):1-11. doi:10.1371/journal.pone.0244925

7. Endriyas M, Kawza A, Alano A, et al. Knowledge and attitude towards COVID-19 and its prevention in selected ten towns of SNNP Region, Ethiopia: Cross-sectional survey. PLoS One. 2021;16(8 August):1-13. doi:10.1371/journal.pone.0255884

8. Kumbeni MT, Apanga PA, Yeboah EO, Lettor IBK. Knowledge and preventive practices towards COVID-19 among pregnant women seeking antenatal services in Northern Ghana. PLoS One. 2021;16(6 June):1-11. doi:10.1371/journal.pone.0253446

9. $\mathrm{Pu}$ J, Mei H, Lei L, et al. Knowledge of medical professionals, their practices, and their attitudes toward traditional Chinese medicine for the prevention and treatment of coronavirus disease 2019: A survey in Sichuan, China. PLoS One. 2021;16(3 March):1-10. doi:10.1371/journal.pone.0234855 
10. Nwagbara UI, Osual EC, Chireshe R, et al. Knowledge, attitude, perception, and preventative practices towards COVID-19 in sub-Saharan Africa: A scoping review. PLoS One. 2021;16(4 April):1-20. doi:10.1371/journal.pone.0249853

11. Ode L, Sety M, Kusnan A, Pasca P, Kesehatan S, Oleo UH. Pengaruh Edukasi Melalui Media Leaflet Terhadap Pengetahuan Dan Sikap Siswa SMAN 14 Bombana. 2021:67-77.

12. Defar A, Molla G, Abdella S, et al. Knowledge, practice and associated factors towards the prevention of COVID-19 among high-risk groups: A cross-sectional study in Addis Ababa, Ethiopia. PLoS One. 2021;16(3 March):1-14. doi:10.1371/journal.pone.0248420

13. Notoatmodjo S. Metode Penelitian. Jakarta: Rineka Cipta; 2010.

14. Notoatmodjo. S. Promosi Kesehatan Dan Ilmu Perilaku. Jakarta: Jakarta: Rineka Cipta; 2012.

15. Pakpahan M dkk. Promosi Kesehatan Dan Perilaku Kesehatan. Jakarta: Yayasan Kita Menulis; 2021.

16. Purnamasari V., Efendi F. Upaya Peningkatan Pengetahuan Pencegahan Covid-19 dengan Menggunakan Leaflet pada Pasien Rawat Jalan Di UPTD Puskesmas Pare Kabupaten Kediri 2021. J Kesehat Pena Med. 2021;11(1):89-99.

17. Martini M, Putra N. dkk. Pengaruh Pelaksanaan Pendidikan Kesehatan (Health Education) Kepada para Pedagang Menggunakan media Pembelajaran: Leaflet dalam Meningkatkan Pengetahuan tentang Pencegahan Covid 19 di Pasar Benyuning Buleleng. Pros Semin Nas. 2020;2(1):45-50.

18. Wulandari TS, Anisah RL, Fitriana NG, Purnamasari I. Pengaruh Pendidikan Kesehatan dengan Media Leaflet untuk Meningkatkan Pengetahuan dan Perilaku dalam Upaya Menerapkan Protokol Kesehatan pada Pedagang di Car Free Day Temanggung. J Ilm Kesehat. 2020;10(2):615.

19. Jaji. Pengaruh Pendidikan Kesehatan dengan Media Leaflet Terhadap Pengetahuan Warga dalam Pencegahan Penularan Covid 19. Procedding Semin Nas Keperawatan. 2020;6(1):135-140.

20. Tedju Hinga, I, A., 2019. Efektivitas Penggunaan Media Poster dan Leaflet dalam Pendidikan Kesehatan Reproduksi terhadap Peningkatan Pengetahuan Masyarakat di Kabupaten Belu. CHM-K Applied Scientifics Journal Vol. 2 No. 3 September 2019.

21. Wulan S, Gurusinga R. Penyuluhan Protokol Kesehatan dengan Media Video dan Leaflet Terhadap Pengetahuan dan Sikap Lansia Tentang Pencegahan Covid-19. J Pengmas Kestra. 2021;1(1):34-37. doi:10.35451/jpk.v1i1.707

22. Maryani D, Himalaya D. Pengaruh Leaflet Covid-19 Terhadap Ibu Dan Bayi Pada Masa Pandemi di Praktik Mandiri Bidan. Oksitosin J Ilm Kebidanan. 2021;8(2):116-127.

23. Darmayanti S, Sumekar A. Efektivitas Edukasi Tentang Pemilihan Jajanan Sehat Melalui Media Visual Leaflet Terhadap Perubahan Pengetahuan dan Sikap Siswa Sekolah Dasar Kanisius Kadirojo di Kecamatan Kalasan, Kabupaten Sleman Yogyakarta. J Kesehat Masy. 2021;14(1):392-400. 